\title{
化学工業におけるミつロ技術の現状 \\ Current Topics on Micro Technology in the Chemical Industry
}

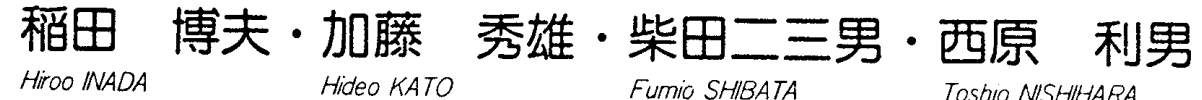 \\ Fumio SHIBATA \\ TOShio NISHIHHARA}

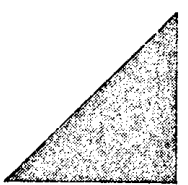

口複合化による高性能化の試みがある。従来, 複 合化といえば 2 種類のポりマーを単に混合するポ リマーブレンド〔図 1 (a))が主であり性能もそ れほど特殊なものは期待できなかったが，成形法 などの工夫により高度に相コントロールさせ，こ れにより飛躍的に性能を向上させるという手法が 提案されてきた。 2 種類のポリマーが分子状に互 いに絡合い構造となるIPN〔図1(b))，剛茞なポ リマーがマトリックス樹脂中にミクロに分散され た分子複合体〔図 1 (c)〕と呼ばれるのがそれで ある、本稿では特に高強度材料として注目される 分子複合体について述べてみる。

1.2 分子複合体の技術と現状強化複合材 料は，高強度・高弾性係数の強化瀻維をマトリッ クスポリマー中に含浸させることによって得られ るが，強化緎維の代わりに剛直な棒状分子にその 機能を持たせ，この補強分子を数十 $\mathrm{nm}$ 以下の才 ーダで分散せしめた複合材料，いわゆる分子複合 体の研究が進められてきている。分子複合体はマ クロ複合材料（例えば，ガラス瀻維強化エポキシ 樹脂）に比べて，その成形方法と補強成分の微小 分散の故に，界面の按着の問題が少なく，また， 成分ポリマーの熱膨張係数の差から生じる熱応力 ひずみが小さいと期待され，さらに，補強成分ポ リマーの配向と量をコントロールすることで用途

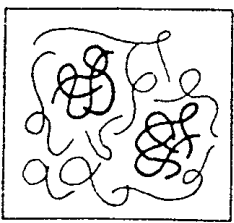

(a)

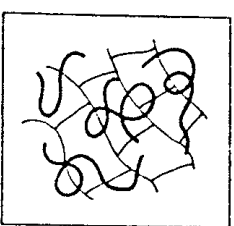

(b)

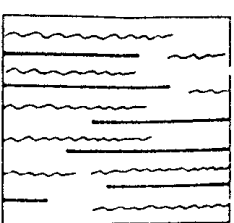

$1 c$
図 1 ポリマーの複合形態 
に応じた力学特性の材料を成形しやすいと言われ ている。

高柳は, 補強ポリマーとしてポリ-P-フェニレ ンテレフタールアミド（PPTA）などを用い，マ トリックスポリマーにはナイロンを始めとした屈 曲性の骨格構造を有する各種ポリマーの系で, マ トリックスポリマー中にPPTAを均一に分散さ せ性能向上を図ってきた。 $5 \%$ に満たない補強ポ リマーの添加でマトリックスポリマーの降伏応力 が 2，3倍増加した。電子顕微鏡観察によると補 強分子がミクロフィブリルの三次元ネットワーク 構造を形成し, PPTAの分散の小さなものでは 1.5〜30 nm を観測している ${ }^{(1)}$.

一方, アメリ力空軍枋料研究所の Helminiak らは補強ポリマーに全芳香族へテロ環ポリマー, すなわちポりーP-フェニレンベンゾビスチアゾー ル (PPBT), ポリーP-フェニレンベンゾビスオ キサゾール（PPBO）などを用い, 繊維形態では 弾性係数がそれぞれ $310 \mathrm{GPa}, 420 \mathrm{GPa}$ と優れた 性能のものを得ており ${ }^{(2)(3)}$, 高性能分子複合材料 はより具体的なものとなってきた。

しかし，実際の分子複合体シートは積層して使 用目的に応じた成形物にする必要があるが，融着 性と配向性を同時に満足させるものはまだない。

そこで筆者らは補強ポリマーとしてPPBTを， マトリックスとして，それ自身も成形物の弾性係 数向上に寄与し，かつフィルムの熱融着性が可能 である芳香族共重合ポリアミドを用いて検討を進 めてきた，従来の等方性溶液からの製膜方式で は, 弾性係数が $63 \mathrm{GPa}$ と低いものであったが, 温度変化による異方性から等方性への相転移の過 渡状態で成形することにより，引張弾性係数が繊 維形態で $143 \mathrm{GPa}$ と理論推定值にほほ等しいも のを得，テープ形態では $120 \mathrm{GPa}$ を得た。この テーブは積層することが可能で, 厚さ $2.5 \mathrm{~mm}$ の 積層物は曲げ弾性係数 $102 \mathrm{GPa}$ の高い值を有し ている。この系ではPPBT 分子が数十 nmの径 で針状に分散しているのが SEMで観測され $た^{(4)}$.

補強ポリマーにPPBTを用いたものは, 溶媒 は強酸が主体であるが，横田らはポリイミドの前 駆体のポリアミック酸を有機溶媒に溶解して分子 分散せしめる方式で, 補強, マトリックスポリマ

日本機械学会誌
一成分にそれぞれP-フェニレンジアミン，3， 3’ジアミノジフェニルエーテルを用いた系で弾性 係数 $60 \mathrm{GPa}$ のイミドフィルムを得, 力学粘弾性 測定から均一分散であると報告している(5). 以 上, 分子複合体について最近の研究の流れを述べ たが，新たな複合材料の一つとして今後発展する ものと期待される。

\section{2. 磁気記録材料用ベースフィルムの表面設計}

$2 \cdot 1$ はじめに磁気記録材料は，ビデオ， オーディオ，コンピュータテープおよびフロッピ 一ディスクとして発展しており，その基材にはほ とんどの埸合，寸法安定性，強度，コストの面で 俖れたポリエチレンテレフタレート (PET) フ イルムが用いられている。

近年磁気記録材料は，磁性体の高性能化ともあ いまって高記録密度化へのめざましい技術進歩を とげている．ビデオテープはその代表的なもので あり, VHS, $\beta \cdot \max や 8 \mathrm{~mm}$ 方式では $0.2 \sim 0.5$ $\mathrm{m}^{2} / \mathrm{h}$ の高記録密度を達成している。高記録密度 に扔いても高画質を得るには基材フィルムの表面 は平たんであるのが望ましいが，一方，表面が平 たんになるとテープの走行性やフィルムの巻取り 性が悪化するという問題がある。この相反する二 つの要求を満たすフィルムの表面設計が必要であ る.

本文では，ビデオテープのドロップアウトと電 磁変換特性と走行耐久性に関して，フィルムの表 面性が及ぼす影響についてのべる。

$2 \cdot 2$ ドロップアウト（DO） テープの表面 にごみが付着したり, 粗大突起が存在すると, へ ッドはその部分でジャンプして信号を記録または

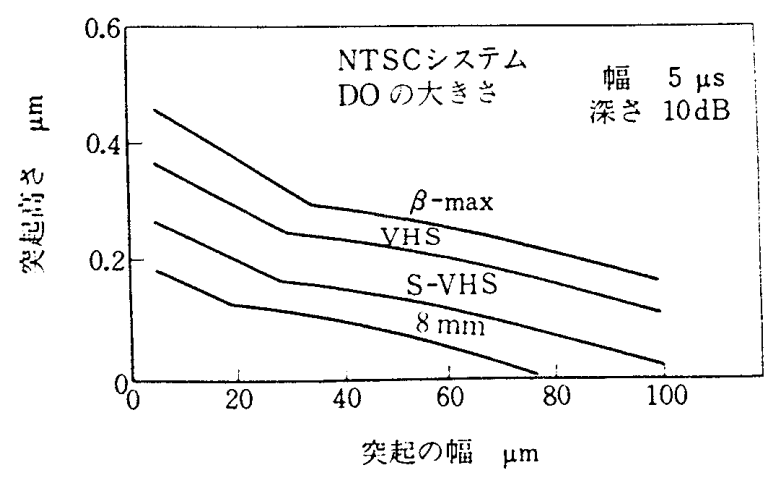

図 2 DO となる突起の計算例 
再生できなくなりDO となる，DOが多いと再生 画面に筋が入り見にくくなるためその原因物を除 く必要がある，DOになる突起サイズを計算する と図 2 のようになり，方式によって異なるが，高 さ $0.2 \mu \mathrm{m}$, 幅 $10 \mu \mathrm{m}$ と小さな突起でも DOをも たらすことがわかる．PETフィルム内の粗大笑 起は，原料のクリーン化およびフィル夕の強化に より極めて少なくなってきた。しかしフィルムお よびテープの製造工程で発生する削れ粉・切粉な どの付着異物はまだ多く，しかも $\phi 1 \mu \mathrm{m}$ の微小 物でもDO となる確率が高い，FT-IR・XMA や レーザラマンなどの分析手段によって物質を同定 し，製造技術また削れ性に強いPET フィルムの 改善にフィードバックされている.

\section{$2 \cdot 3$ 電磁変換特性ＰETフィルムの表面} 突起は，磁性面に浮き出たり，テープ加工時に巻 きじまり転写によって磁性面に凹みをつけてテー プ表面を荒す。磁性面が荒くなるとへッドとの間 に大きなスペーシングロスが発生し，信号近傍で の変調ノイズが大きくなり $\mathrm{S} / \mathrm{N}$ が低下する，家 庭用 VTRでは色信号は低域変換された AM 信 号であり，FM 信号（輝度信号）のように再生後
にリミッタを通すことができないので磁性面の荒 さはそのままクロマ $\mathrm{S} / \mathrm{N}$ の低下につながる，表 1 にVHS, $\beta-\max , 8 \mathrm{~mm}$ ビデオの記録信号 波長を示した。磁性面の凹凸が記録波長より大き いとノイズになりやすいので，特にクロマ信号波 長より小さい周期の山凸の磁性面をつくるのが好 ましい.

図 3 に市販ビデオテープ用の PET フィルムの 表面粗さを示した。高密度・高画質を要求される テープほど平たんなフィルムが用いられているこ とがわかる，特に蒸着テープでは，べースフィル 么の表面凹凸がそのまま磁性面の形状となるため に極めて平たんで異物のないフィルムが用いられ ている。

$2 \cdot 4$ 走行耐久性 PETフィルムの表面凹 凸は，無機粒子の添加または触媒粒子を析出させ

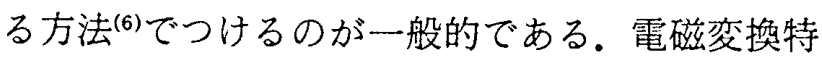
性を向上させつつ走行耐久性を向上させるため に，表面突起の大きさ，頻度，形状などに工夫が されている(7)，例えば図 4 に示したように，扁平 な粒子を用いるより球状粒子を用いる方が同程度 の表面粗さでも走行耐久性に優れていることがわ

表 1 各方式の記録信号周波数と波長（NTSC）

\begin{tabular}{c|c|c|c|c}
\hline \multirow{2}{*}{ 方周波数と } & \multicolumn{2}{|c|}{ 信 号 周 波 数 } & \multicolumn{2}{|c}{ 記 録 } \\
\cline { 2 - 5 } & ビデオ $(\mathrm{Y})$ & クロマ $(\mathrm{C})$ & ビデオ \\
\hline $\mathrm{VHS}$ & $3.4 \sim 4.4 \mathrm{MHz}$ & $629 \mathrm{kHz}$ & $1.3 \sim 1.7 \mu \mathrm{m}$ & クロマ $\left(\lambda_{c}\right)$ \\
\hline$\beta-\mathrm{max}$ & $3.6 \sim 4.8$ & 688 & $1.5 \sim 1.9$ & $9.3 \mu \mathrm{m}$ \\
\hline $8 \mathrm{~mm}$ ビデオ & $4.2 \sim 5.4$ & 743 & $0.7 \sim 0.9$ & 10.1 \\
\hline
\end{tabular}

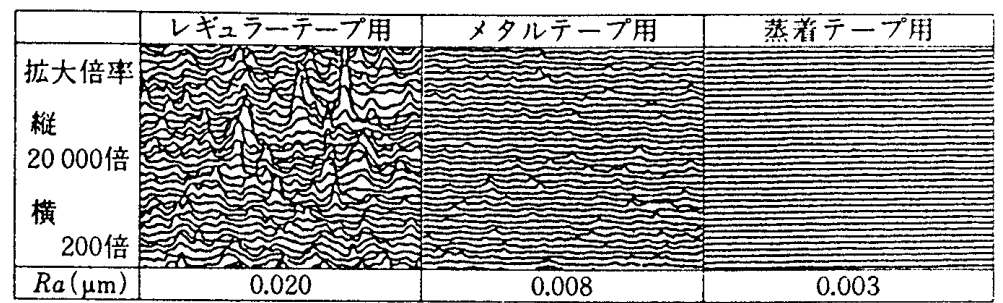

図 3 市販ビデオテープ用 PETフィルムの表面性（代表例）

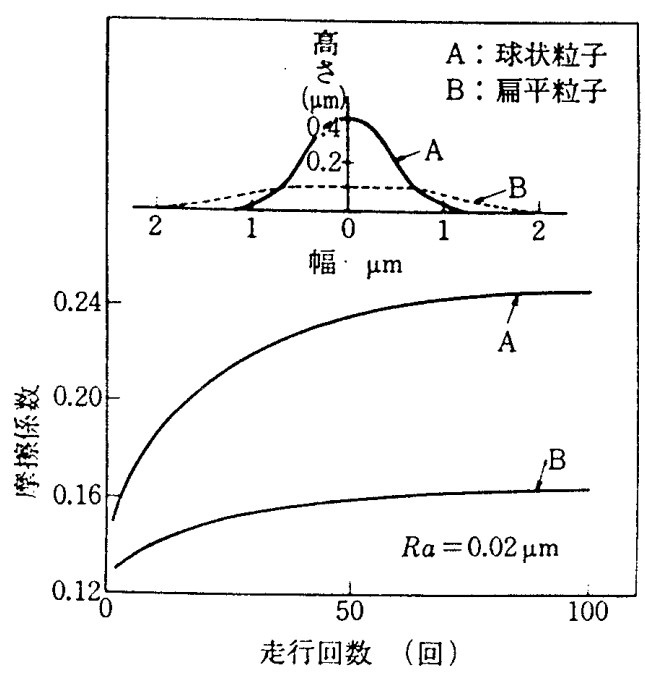

図 4 フィルム表面突起形状と走行摩擦係数 
かる．その他同一形状の突起であれば突起が高い 方が走行性が良く，また頻度が多い方が耐久性が ある。また大粒子と小粒子の組合せも考えられて いる(8).

しかし，図 3 に示したメタルテープ用のグレー ドでは，上記の工夫をしても走行耐久性が不十分 なために，テープにバックコートを付与し使用さ れている.

以上のべたごとく，磁気記録用の PET フィル ムは平たん易滑で，耐久性に優れ，買物がなく， しかも安価であることをめざして検討がすすめら れている。

\section{3. 極細瀻維の応用}

$3 \cdot 1$ はじめに 普通のナイロンやポリエス テル繊維の太さは $2 \sim 3$ デニール $(9000 \mathrm{~m}$ の重 さが $2 \sim 3 \mathrm{~g}$ ）程度あるのに比べ, 極細織維は 1 デニール以下の太さである，極細繊維が最初に応 用されたのは人工皮革の分野で昭和 40 年半ばの ことである。現在は，コートなどの衣料用，家 具, 自動車の内装材として使われている，最近特 に注目されているのはスポーツ衣料織物の中で蒸 気（汗，湿気）は通すが水の浸透は防止するとい う「透湿防水織物」である。この織物には高密度 織物が使われている，経系や緯系の密度を増やし ていくとこの織物が得られるが，普通の太さの系 を使ったのでは風合が硬くなって衣料用には好ま しくない.
そこてこの極細繊維が再び注目された。極細緎 維を使った高密度織物では風合が硬くならないだ けでなく織物組織間や単繊維間の空げきが小さく なり水の浸透を防止する効果も出てくる。もっと も，ポリエステル繊維やナイロン繊維の水に対す る接触角は小さい $\left(69^{\circ} \sim 75^{\circ}\right)$ ので，単にち密な 織物にするだけでは防水効果は生まれない，防水 効果を得るためには，この高密度織物にふつ素系 の樹脂やシリコン系の樹脂を用いたはつ水処理を することが必要である。また，極細繊維の特徵と して細いことによって表面䅡が非常に大きくなる ことがあげられる。このために，極細緎維を使つ た布常は織物組織竹編物組織を工夫することで優 れたワイピング性能を発揮する。

ここでは極細繊維高密度織物にはっ水処理をし た透湿防水織物と，目鏡拭きなどのワイピング布 离を紹介する。

$3 \cdot 2$ 透湿防水織物 ${ }^{(9)}$ 上述のごとく極細織 維を使って高密度織物を製織し，これに撥水樹脂 加工を行うことで透湿防水織物が得られる。

䓟密度織物形の透水布帛は防水性（JIS L 1092 による耐水度）がやや低い（耐水度 500 1000 $\mathrm{mm}$ 水柱程度)。少しでも耐水度をあげるために 繊維間空げきを小さくする目的で一般には熱プレ ス処理（カレンダー加工）を実施する。 そのため に織物表面が平滑になっている，表面が平滑であ ると水滴が付着した時, 接触面積が大きくなり水 滴はすばやく転がり落ちない，天然の蓮やサトイ モの葉の上では水滴はころころと水銀のように転

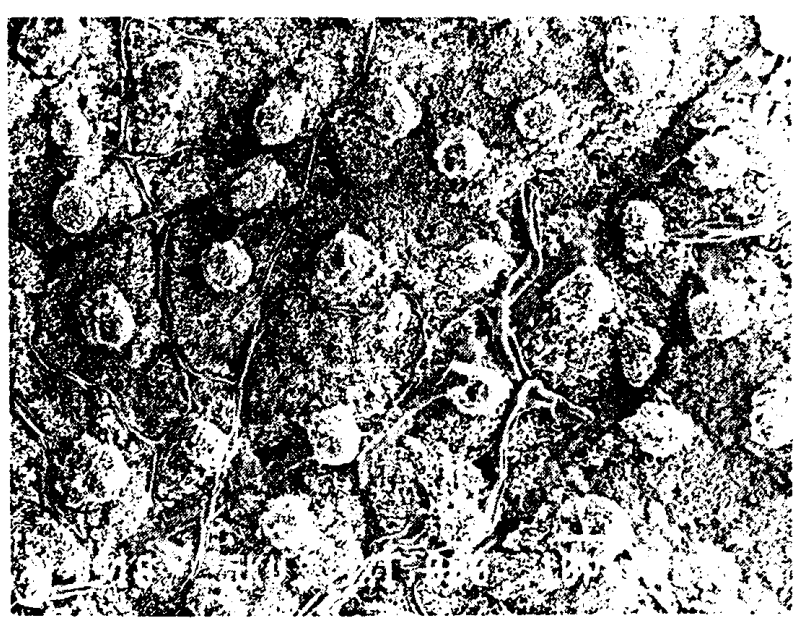

(a) 蕅の莱

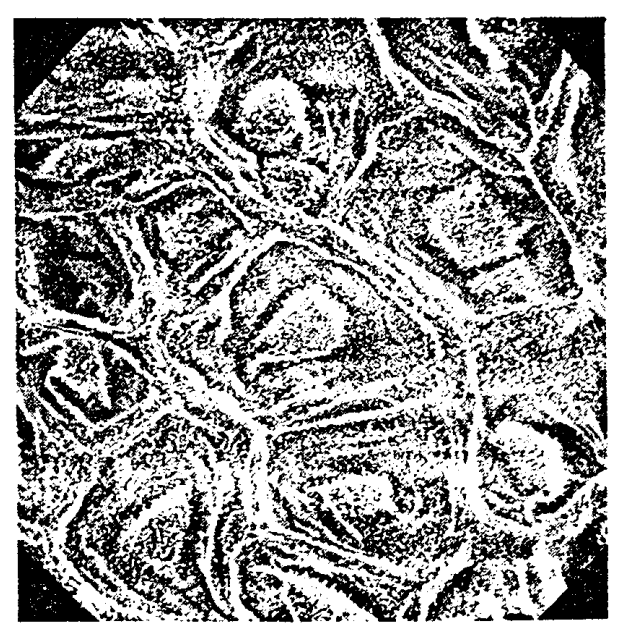

(b) サトイモ日笨

図 5 表面電子曗微鏡写真 


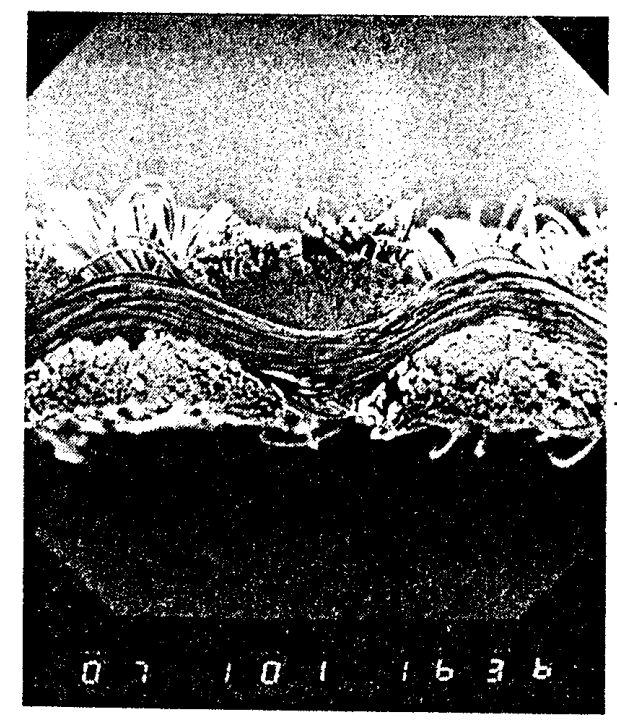

(a) 特殊極細瀻維高密度織物

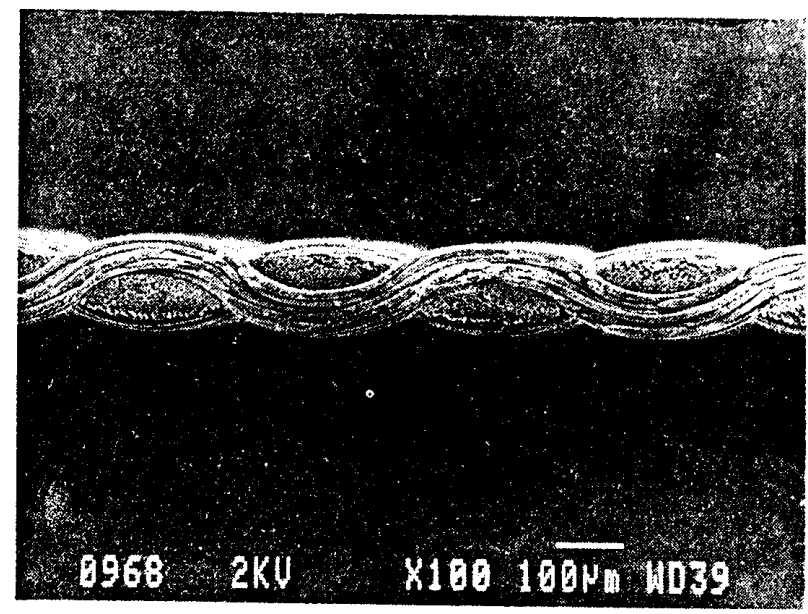

(b) 一般極細絨維高密度織物

図 6 極細瀻維高密度断面電子顕微鏡写真

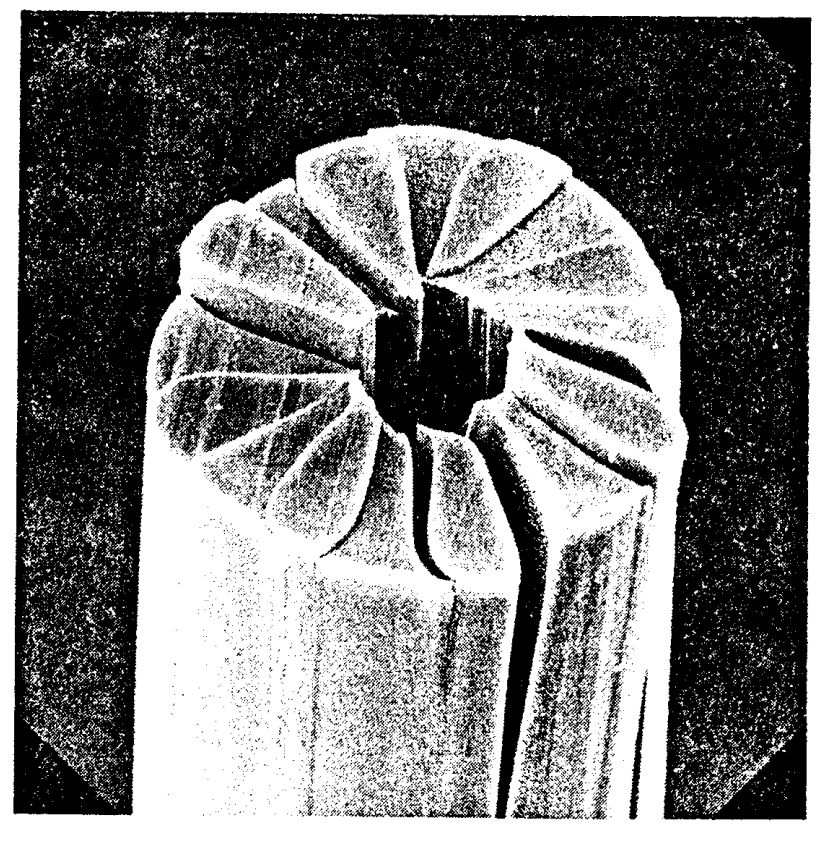

図 7 分割形極細瀻維の断面

がる．電子顕微鏡でみると葉の表面は一面が微細 な凹凸で覆われていて，水滴はこの微細凹凹と微 細凹凸の間に固定される空気との複合境界面で接 触する。この複合境界面の界面張力は空気の存在 のために著しく小さくなり, その結果, 水滴は物 理的に安定な球状に近くなりよく転がる。図 5 (a)，(b)に蓮とサトイモの葉の表面電顕写真を示 す.

透湿防水織物の中には，空気を抱え込みやすい 特殊な形状の極細纎維を高密度に織りあげた後,

Jour. JSME

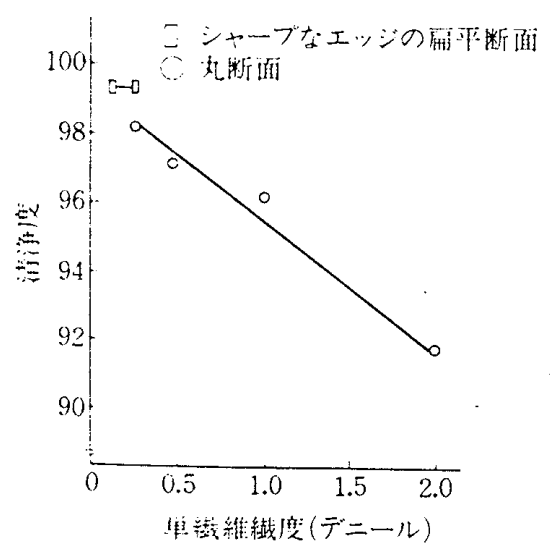

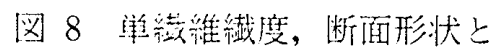
ワイヒンング後の清浄度

一般の高密度織物と同椂に撥水樹脂加工を行って 得られた特殊極細繊維を使った高密度織物があ る.撥水性能が蓮の葉やサトイモの葉と同様に優 れていて，水滴が付いた場合に一般の極細繊維高 密度織物とは違って水滴はよく転がる。また，こ の特殊極細繊維高密度織物の断面電䫓写真と一般 の極細繊維高密度織物のそれを図 6(a), (b) に示 す。これらの写真から特殊極細繊維高密度織物の 表面が蓮の葉やサトイモの葉の表面のように微細 凹凹構造になっているのが理解される。

上述のように, 特殊極細繊維高密度織物は透湿 防水織物の中でもはっ水性が特に優れており，こ のためにスポーツ衣料分野やコートなどの外衣の 分野で国内外で広く使用されている。 
3・3 ワイピング布帛ポリエステル/ナイロ ンよりなる分割形極細繊維の断面例を図 7 に示 す。この極細繊維は写真にみられるようにシャー プなエッジを持つ扁平断面形状の 0.2 デニールの 織維である．このシャープなエッジと極細織維の 広表面積とでミクロな污れをきれいにふきとるワ イピング性能が生まれる。単系デニール（太さ） と清浄度の関係を図 $8^{(10)}$ に示す。

縦軸の清浄度は, 清浄なガラス面の鏡面光沢度 （A）とたばこの煙を付着させたガラス板を各種 単系デニールの異なる系で作ったワイピングクロ スで拭きとった後のガラス面の鏡面光沢度 $(B)$ を測定し， $B / A \times 100$ の値で示したものである. このように細くてシャープなエッジを持ったもの が清浄性が優れており，また，被ワイピング面を 傷つけない, 吸水性と吸油性に優れている, 低発 塵性である，洗たくすれば何度でも使用できるな どの特徵をも併せもっているので眼鏡, カメラな どの精密レンズ, コンパクトディスクやOA 機 器, 電気製品, 宝石類, 漆器, 楽器などの高級ワ イピングクロスとして幅広く使用されている。

\section{4.まと め}

化学工業におけるミクロ技術の話題として本稿
では高分子材料への適用例の一部を紹介した。

傮れた高分子素材へ高度なミクロ技術を適用す ることにより，今まで考えられなかった高性能， 高機能材料を創り出し得ることを示した。

この傾向は今後ますます強まり，化学工業にお けるミクロエンジニアリングの重要性はいちだん と增すと考えられる。

\section{文献}

(1) Takayanagi, M., Pure \& Appl. Chem, 55-819 (1983).

(2) Allen, S.T., Ph. D. 173, (1983), University of Massachusetts.

(3) 国際特許, No. WO85/04178.

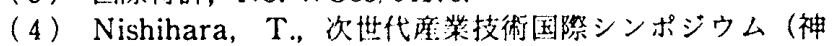
F), (1988-3), 23.

(5) Yokota, R., ほか 4 名, J. Polymer Sci. Letters, 26-715 (1988).

(6) 特公昭 53-4103 (1978).

(7) 特開昭 63-108037 (1988).

(8) 特公昭 58-3289 (1983).

（9）柴田三三男・川蛣俊三，緎維機栈学会誌，44-3 (1989), 95.

（10）今村 染色工業，37-3（1989），10.

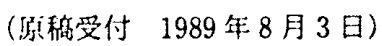

